\title{
Signs systematically studied: Invitation to Peirce's theory
}

\author{
Ahti-Veikko Pietarinen \\ Chair of Philosophy, Tallinn University of Technology \\ Akadeemia tee 3, 12618 Tallinn, Estonia \\ e-mail: ahti-veikko.pietarinen@ttu.ee
}

\begin{abstract}
This introductory presentation reviews noteworthy topics and concepts in Peirce's interrelated kingdoms of the theory of signs, their classification, categories, logic and semeiotic.
\end{abstract}

Keywords: Charles Peirce, categories, signs, classification, logic, semeiotic

CHARLES SANTIAGO SANDERS PEIRCE (c.1839), son of the mathematician Benjamin P., brought up in a circle of physicists and naturalists, and specially educated as a chemist, derived his first introduction to philosophy from the K.d.R.V. [Immanuel Kant's Critique of Pure Reason, 1781] and other celebrated German works, and only later made acquaintance with English, Greek, and Scholastic philosophy. Accepting unreservedly Kant's opinion that the metaphysical conceptions are merely the logical conceptions differently applied, he inferred that logic ought to be studied in the spirit of the exact sciences, and regarded Kant's table of functions of judgment as culpably superficial. (MS L 107: 1, 26 October 1904, Auto-Biography for Matthew Mattoon Curtis, Draft C, marked "final" by Peirce.)

Thus begins Peirce's sketch of his autobiography, which was never published in his lifetime. ${ }^{1}$ Peirce's theory of signs is a colossal theory of representation, reasoning, meaning, communication and signification, never made available in print in full. ${ }^{2}$

1 For partial publications of Peirce's autobiography in MS L 107, see Ketner 1983 and Stuhr 1987. The present article is a revised and abridged version of the introduction to Peirce's theory of signs that appeared in Pietarinen 2006a, Ch. 1.

2 The selections include the Collected Papers of Charles S. Peirce (CP), the critical and chronological edition of the Writings of Charles S. Peirce: a Chronological Edition (W), the Essential Peirce (EP), PW and SS (see bibliography). Large portions of his writings on the theory of signs and semeiotic remain unpublished, with the essential material concerning especially his later attempts from 1905 onwards found only in the manuscripts and correspondence (MS, MS L). 
The development of his theory of signs was systematic and its erection architectonic. Its philosophical underpinnings have their origins in his system of categories. Our introduction begins with these categories and then moves on to present some of the most noteworthy topics and concepts found in his interrelated kingdoms of the theory of signs, logic and semeiotic.

\section{Firstness, secondness, thirdness}

No reference to categories is possible without a reference to Kant. Kant's influence indeed shows up in a number of junctures in Peirce's philosophy. The categories Peirce ended up advocating, the cenopythagorean categories, are a simplification of Kant's twelve categories of metaphysics into three: the division of what pertains to the category of firstness, to the category of secondness, and to the category of thirdness. These refer to the three categories of quality, reaction and representation. The characteristic ontological furniture of these categories can make reference to being of the nature of possibility, that of actuality, or that of laws and generalities.

Unlike Kant, Peirce never approved the distinction between things in themselves and the phenomenal world. Moreover, Peirce's categories are not meant to be universally applicable to everything there is or may be. They are the most pertinent in the branch of philosophy known as phenomenology, or phaneroscopy, as Peirce later renamed that study. The purpose of phaneroscopy is to contemplate universal phenomena and to discern ubiquitous elements of these three categories.

Firstness is the mode or element of being by which any subject is such as it is, positively and regardless of everything else; or rather, the category is not bound down to this particular conception but is the element which is characteristic and peculiar in this definition and is a prominent ingredient in the ideas of quality, qualitativeness, absoluteness, originality, variety, chance, possibility, form, essence, feeling, etc. (MS L 107: 21)

Firstness contains pure modes of being, objects and things without presupposing interventions of the human mind. The ideas of "freshness, life, freedom" (CP 1.302, c. 1894) characterize such modes. What is firstness must be unanalysable, immediate and simple, and must not depend on cognitions of a mind or actions of an agent. Firstness may be a feeling, but it has to be immediate, placed upon a mind that experiences and feels in an instantaneous and durationless fashion, without deliberation, recognition and interpretation. Examples are "the quality of the emotion upon contemplating a fine mathematical construction, the quality of falling in love" (CP 1.304, c. 1904), and "a feeling of stillness" (CP 8.330, 1904). In the Logic Notebook Peirce speaks of a "flavor" of all that is present, the quality of what is as it is, regardless of anything else: "all that is 
collectively taken in its absolute simplicity is flavor". ${ }^{3}$ The Dao that can be named is not the real Dao. ${ }^{4}$

The second major division of inquiry is "Normative Science, which investigates the universal and necessary laws of the relation of Phenomena to Ends, that is, perhaps, to Truth, Right, and Beauty" (CP 5.121).

Secondness is that mode or element of being by which any subject is such as it is in a second subject regardless of any third; or rather, the category is the leading and characteristic element in this definition, which is prominent in the ideas of dyadic relativity or relation, action, effort, existence, individuality, opposition, negation, dependence, blind force. (MS L 107: 22)

Unlike firstness and its still-life quality of the absence of thought and action, secondness is the dynamic, two-sided encounter and opposition found in the polarities of action-reaction, effort-resistance, temporal passing from one instant to another, or the contact of the ego (the mind) with the non-ego (the non-mind). All these involve the effort of acting and perceiving, the struggle to achieve something and to feel something, the shock of sensing change. One element in the coupled system desires the other; one cymbal rings, but thrown together, two cymbals make a sound. Action cannot exist without reaction, effort without resistance. Singular things preserve their existence only in so far as there is a counterpart that resists or acts against it. When we all know beauty as beauty, there arises ugliness. When we all know the good as good, there arises evil.

In a letter to Lady Welby, Peirce explains firstness, secondness and the transitional phase to thirdness in an irresistible way worth quoting in length:

The type of an idea of Secondness is the experience of effort, prescinded from the idea of a purpose. It may be said that there is no such experience, that a purpose is always in view as long as the effort is cognized. This may be open to doubt; for in sustained effort we soon let the purpose drop out of view. However, I abstain from psychology which has nothing to do with ideoscopy. The existence of the word effort is sufficient proof that people think they have such an idea; and that is enough. The experience of effort cannot exist without the experience of resistance. Effort only is effort by virtue of its being opposed; and no third element enters. Note that I speak of the experience, not of the feeling, of effort. Imagine yourself to be seated alone at night in the basket of a balloon, far above earth, calmly enjoying the absolute calm and stillness. Suddenly the piercing shriek of a steam-whistle breaks upon you, and

\footnotetext{
3 MS 339: 222r, 22 July 1902. I abbreviate the Logic Notebook as LN, followed, when provided, by page, date and title.

4 References to Dao De Jing are from the translations by Lin Yutang, The Wisdom of Laotse, Beijing: Foreign Language Teaching and Research Press, 2009.
} 
continues for a good while. The impression of stillness was an idea of Firstness, a quality of feeling. The piercing whistle does not allow you to think or do anything but suffer. So that too is absolutely simple. Another Firstness. But the breaking of the silence by the noise was an experience. The person in his inertness identifies himself with the precedent state of feeling, and the new feeling which comes in spite of him is the non-ego. He has a two-sided consciousness of an ego and a non-ego. That consciousness of the action of a new feeling in destroying the old feeling is what I call an experience. Experience generally is what the course of life has compelled me to think. Secondness is either genuine or degenerate. There are many degrees of genuineness. Generally speaking genuine secondness consists in one thing acting upon another, - brute action. I say brute, because so far as the idea of any law or reason comes in, Thirdness comes in. When a stone falls to the ground, the law of gravitation does not act to make it fall. The law of gravitation is the judge upon the bench who may pronounce the law till doomsday, but unless the strong arm of the law, the brutal sheriff, gives effect to the law, it amounts to nothing. True, the judge can create a sheriff if need be; but he must have one. The stone's actually falling is purely the affair of the stone and the earth at the time. This is a case of reaction. So is existence which is the mode of being of that which reacts with other things. But there is also action without reaction. Such is the action of the previous upon the subsequent. (CP 8.330, 1904, Letter to Welby)

Numerous threads run wild in this lengthy passage, including the distinction between generate and degenerate forms of secondness. This split is explained below; Peirce needed it to avoid the pitfalls of demarcating what belongs to secondness and what to thirdness. He also mentions ideoscopy, which "consists in describing and classifying the ideas that belong to ordinary experience or that naturally arise in connection with ordinary life, without regard to their being valid or invalid or to their psychology" (CP 8.328).

Clearly psychology is not of aid in the effort of providing basic principles for logical and semeiotic theory. How Peirce avoids psychological notions in his allpervading concept of the sign is worth noting. He says "that a Sign brings a Second, its Object, into cognitive relation to a Third", "that a Sign brings a Second into the same relation to a first in which it stands itself to that First", and that "if we insist on consciousness, we must say what we mean by consciousness of an object. Shall we say we mean Feeling? Shall we say we mean association, or Habit?"5 Instead of implying psychological undertones, Peirce emphasized communicational relations that mark

5 See Pietarinen 2014b for a complete transcription of MS 499, 1906, On the System of Existential Graphs Considered as an Instrument for the Investigation of Logic. MS 499 is a follow-up of MS 498 (On Existential Graphs as an Instrument of Logical Research). Prepared as introductory remarks for the address to the 1906 meeting of the National Academy of Sciences, MS 490, wrongly titled and inappropriately transcribed in CP as [Introduction to Existential Graphs and an Improvement on the Gamma Graphs], is the version Peirce ended up presenting at the April meeting in Washington, D.C. 
connections between signs and minds. His terminology refers to cognitions as well as to the mental, but in the context of his theory of signs that talk does not take us into the realm of psychology.

Resistance to psychology is reminiscent of Kant's conviction of the absurdity of admitting logic to be governed by psychological facts:

Some logicians presuppose psychological principles in logic. But to bring such principles into logic is as absurd as taking morality from life. If we took the principles from psychology, i.e. from observations about our understanding, we would merely see how thinking occurs and how it is under manifold hindrances and conditions; this would therefore lead to the cognition of merely contingent laws. In logic, however, the question is not one of contingent but of necessary rules, not how we think, but how we ought to think. (Kant 1988[1783]: 16)

The seeds of another of Peirce's doctrines are clear in the last sentence: logic, like ethics, is a normative science. This idea was absorbed well by Frank Ramsey, who transferred Peirce's thoughts to Wittgenstein who began to show signs of appreciating them. In linguistics, parallel discussions on the normative basis of language emerged in the wake of the early structuralist-functionalist-conventionalist debates, only to be brushed aside from the mainstream linguistics just as they were from the better part of the 20th-century formalist approaches to logic, philosophy and science.

The above quotation from Peirce's letter continues with a discussion of whether the idea of determination by action involving considerations of time - the previous upon the subsequent - is the "pure idea of secondness" or whether it involves thirdness. The Kantian sense was that indeterminacy belongs to the future: it is an idea that does not concern existence, and only existence is determinate. Peirce remained indecisive about whether there could be something in the secondness/thirdness interface that arises in contemplating "action without reaction".

Be this as it, Peirce describes a distinct category of thirdness in his autobiography as follows:

Thirdness is that mode or element of being whereby a subject is such as it is to a second and for a third; or rather, it is the characteristic ingredient of this definition, which is prominent in the ideas of instrument, organon, method, means, mediation, betweenness, representation, communication, community, composition, generality, regularity, continuity, totality, system, understanding, cognition, abstraction, etc. (MS L 107: 22-23)

Peirce took the category of thirdness to be of utmost importance in philosophy. It stands out in the ideas that our minds produce. It is something that cannot be reached by the sole consideration of secondness. Peirce had many reasons to favour 
this category, but the truly compelling one is the proof which he set up in the algebraic and diagrammatic systems, that triadic relations are irreducible to monadic and dyadic relations. In any triadic relation, Peirce claimed, there in fact is an element of the mental. A case in point is the three-place relation of giving, such as in "giving a horse to a trainer". It involves a law that makes the receiver (here the indirect object "a trainer") a possessor of something (the absolute term "a horse") by the sender's action. The relation of giving cannot be reduced to two identities of (1) one agent putting away a thing and (2) the other agent receiving the thing at a later date.

The third division thus comes to concern metaphysics, which "endeavors to comprehend the Reality of Phenomena. Now Reality is an affair of Thirdness as Thirdness, that is, in its mediation between Secondness and Firstness" (CP 5.121). Semiotically, the sign-object-interpretant trichotomy, explained below, belongs here: "In its genuine form, Thirdness is the triadic relation existing between a sign, its object, and the interpreting thought, itself a sign, considered as constituting the mode of being of a sign. A sign mediates between the interpretant sign and its object. A Third is something which brings a First into relation to a Second" (CP 8.332, 1904). Interpretants and their endless varieties are also described later; essentially, they embrace things such as thoughts, actions, experiences, and qualities of feeling. The Spirit of the Valley never dies.

\section{Speculative grammar, critic, methodeutic}

The second major division of inquiry, theoretical normative science or the science of what ideals things ought to possess, falls into three parts: esthetics, ethics and logic (CP 1.191, 1903). Peirce focused much of his energies on developing the third part, logic, conceived as semeiotic: it is the art of reasoning and the theory of self-controlled, deliberate thought. ${ }^{6}$

Logic as semeiotic is divided into three broad subjects. The first is speculative grammar (pure grammar, stecheotic, stoicheiology). It aims to ascertain what is true of signs (representamens) so that they can embody any meaning (CP 2.229, c.1897). The second is critic (logic proper, stoecheology), the science of classifying arguments and their validity and degree of force. Critic is aimed at ascertaining what is true of signs so that they may hold good of objects. The third is speculative rhetoric (methodeutic, transuasional logic, methodic, methodology), which is the study of methods in the application of truth and about the reference of signs to what they aim at determining,

6 When Peirce writes "logic" he almost invariably also means semeiotics, "the doctrine of the necessary principles of signs”. See MS L 427: 2, Letter to Charles Augustus Strong, 25 July 1904; cf. MS L 75. 
namely the interpretants. Rhetoric is the study of meaning in its full sense, aiming at ascertaining the ways in which signs beget other signs and thoughts beget other thoughts.

The Logic Notebook proposes the following classification (LN: 145r, 29 September 1898): (1) Speculative grammar studies quality, collection, dyadic relation, and triadic relation of copies. (2) Logic proper deals with terms (rhemas), propositions and inferences (see below). (3) Speculative rhetoric concerns methodology, applications of logic to mathematics and other areas of inquiry, and logic in its objective sense. He noted that the term speculative rhetoric "is bad", however, and a few years later coined methodeutic to take its place.

Peirce's semeiotic covers a vast panorama of human inquiry, and is applicable to virtually any discipline and branch of scientific and human inquiry. Charles W. Morris notwithstanding, Peirce's trivium-based division of semeiotic into grammar, logic and rhetoric is not to be narrowly equated with that of syntax, semantics and pragmatics.

\section{Signs, objects, interpretants}

A sign, that sweeping and sublime centerpiece of Peirce's architectonics, appears to be practically anything. We should resist the temptation. But having a wide notion of signs at our disposal is an asset onto which we can project many restrictions. For its essence is in representation: a sign stands to something for something in some respect or capacity (CP 2.228, c. 1897). This one of the most often quoted explanations of signs "standing for something" needs a specification. For example, 'representamen' has a more limited and technical meaning.

That for which a sign stands is its object, with reference to some idea, impression, perception or essence. Signs create in the minds of their interpreters other signs, called their interpretants. In the earlier expositions of his theory of signs he talks about the grounds of representamens. Later he included grounds in interpretants. The reference of the object to an idea can be something that is shared between the interpreters who conceive that idea.

The nature of signs is admittedly made Delphic by Peirce's surprising list of what counts as signs. He claims that a human being, the universe, the thoughts, and our knowledge are all signs. It turns out that at least experience and habit, two cornerstones of Peirce's thought, do not fall under the umbrella of signs. Every sign has its representative quality, its meaning. Meaning, in turn, is a habit, and it is derived from experience. Experience is a reaction between two phases of the mind, the ego and the non-ego, and thus exemplifies secondness. Pure quality, without the presence of a contemplating mind, is firstness. Habit, connected with the mind, is thirdness. 
Peirce believed that we have direct, non-a priori knowledge of all these three categories, and that they must for that reason be beyond doubt (MS 8: 5-6, 1902, On the Foundations of Mathematics). The direct knowledge of signs is the thought, the knowledge of a reaction is experience, and the knowledge of quality is the feeling it creates. Beyond these, the metaphysics that takes these categories and applies them to the totality of the universe is "inferential", by which Peirce means metaphysics as something that represents the processes of coming to have knowledge obtained through signs.

Signs are the only medium through which to bring about and communicate such knowledge. Peirce remarked in several places that "signs are a species of medium of communication" (MS 283: 106, 1905, The Basis of Pragmaticism; cf. MS 793, probably 1906, [On Signs]). In this sense, they are the third element that occupies the space between objects and interpretants. But if signs are a species of a medium, what else is there in communicational situations other than signs that mediate something, and presumably mediate something other than knowledge? For Peirce indeed argues that all our knowledge and thought is acquired through signs (CP 8.332).

Even more overtly, he remarks in several places that every thought is a sign, or in fact in a more qualified sense, that every thought is in signs. Ways of communicating some other things than those that cater for knowledge are disconnected from thought. Such an exceptional type of knowledge unmediated by signs is instantaneous or direct knowledge: something that exemplifies the content of consciousness. Peirce's claim that we do possess such direct or unmediated knowledge of the three cenopythagorean categories seems to mean that exceptional type.

In an early article "Questions concerning certain faculties claimed for man" (CP $5.265,1868)^{7}$ Peirce addressed the question of whether it is at all possible to think without signs:

From the proposition that every thought is a sign, it follows that every thought must address itself to some other, must determine some other, since that is the essence of a sign. This, after all, is but another form of the familiar axiom, that in intuition, i.e., in the immediate present, there is no thought, or, that all which is reflected upon has past. Hinc loquor inde est. That, since any thought, there must have been a thought, has its analogue in the fact that, since any past time, there must have been an infinite series of times. To say, therefore, that thought cannot happen in an instant, but requires a time, is but another way of saying that every thought must be interpreted in another, or that all thought is in signs.

One uses thought to analyse and interpret thought: there is no other way. Still, logic dictates that it is not exactly the same thought that analyses the thought. Thinking is a real, temporal activity, where what is interpreted follows the other in succession,

The paper appeared in 1868 in the Journal of Speculative Philosophy 2: 103-114. 
while the former becomes the representation of the latter. A thought is the sign of its interpretation, or its conclusion.

Signs should not be mistaken for concrete things (MS 9: 1, c.1903, Foundations of Mathematics). They are representations capable of being repeatedly produced and uttered: being precisely alike does not preclude representing separate things. Propositions, which are true or false, or rather are signs capable of turning out to be true or false, are perfections of signs in that they distance themselves from their objects in order to exhibit and produce their representational capacities. A sign is intended to determine, in the minds of its interpreter, its interpretant, which is not identical to the sign that represents or gives rise to it. Even in its most imaginary form, the purpose of the sign is to "communicate ideas" (MS 283: 101) from one state of mind to another, future state of mind. A sign is an "implement of intercommunication" (MS 283: 106), a version of a medium of communication.

In some writings Peirce describes a sign as a "determination of a quasi-mind" (MS 283: 131). Precisely what can be meant by such a determination was a constant struggle. He despaired of clarifying this in MS 283 and elsewhere. One of his attempts articulates thought as a determination of something that "corresponds" to a mind or a quasi-mind. ${ }^{8}$ What he was assured of is that the conception of the quasi-mind is best reached through his logical system of existential graphs (MS 282; Pietarinen 2005b, 2006a). In brief, the quasi-mind, which itself is a sign or a determinable sign, is what the sheet of assertion in that system represents, the sheet upon which the graphs are scribed and which has the potentiality of representing all truths.

An excerpt from one of Peirce's numerous letters to Welby is an instructive explanation of the curious interplay of signs, objects and interpretants which is reached through a logical analysis of science:

It seems to me that one of the first useful steps toward a science of semeiotic $(\sigma \eta \mu \varepsilon i \omega \tau \iota \kappa \eta)$, or the cenoscopic science of signs, must be the accurate definition, or logical analysis, of the concepts of the science. I define a Sign as anything which on the one hand is so determined by an Object and on the other hand so determines an idea in a person's mind, that this latter determination, which I term the Interpretant of the sign, is thereby mediately determined by that Object. A sign, therefore, has a triadic relation to its Object and to its Interpretant. But it is necessary to distinguish the Immediate Object, or the Object as the Sign represents it, from the Dynamical Object, or really efficient but not immediately present Object. It is likewise requisite to distinguish the Immediate Interpretant, i.e. the Interpretant represented or signified in the Sign, from the Dynamic Interpretant, or effect actually produced on the mind by the Sign; and both of these from the Normal Interpretant, or effect that would be produced on the mind by the

8 MS 292: 23, 1906, draft of Prolegomena. To appear in LoF (Pietarinen 2015). 


\begin{abstract}
Sign after sufficient development of thought. On these considerations I base a recognition of ten respects in which Signs may be divided. I do not say that these divisions are enough. But since every one of them turns out to be a triplet, it follows that in order to decide what classes of signs result from them, I have $3^{10}$ or 59049, difficult questions to carefully consider; and therefore I will not undertake to carry my systematical division of signs any further, but will leave that for future explorers. (CP 8.343, 1908, Letter to Lady Welby)
\end{abstract}

The last sentence sets out a research project. Apart from the three major ones introduced below, namely the rhema-proposition-argument, icon-index-symbol and qualisign-sinsign-legisign, later in his life Peirce was working on classifications of signs into myriad divisions. No consensus exists by precisely which methodological principles one should attempt to generate new classifications of signs.

Equally pressing is the question of the systematic connection between the theory of signs and logic. First of all, the study of signs is to be kept clean of psychological influences. MS 499 (Pietarinen 2005c, 2014b) describes the goal by stating that, in order to see the formal relation of signs to their interpreting minds, one has to disregard the qualities of consciousness, the effort of attention, and other psychic ingredients of reasoning. Nevertheless, a sign cannot function "unless it be ultimately interpreted by [a] personal mind; so that if we limit ourselves to concepts, or the mental interpretations of signs, we shall therein include every sign that is a sign in actual function, while if we consider signs regardless of the relation of each to a mind, we neglect to consider a most essential characteristic of signs, and thus make room for errors of logic" (MS 499). Mental discourse is admissible in logic while outright psychologism is not; in other words, the discourse that imports psychological theories and principles into logical lands is debarred. In fact, Peirce was deeply interested in psychology and especially in its experimental aspects and took it to be a subject that might eventually contribute to logic in some novel ways. But he did not think that what makes logical reasoning sound and trustworthy ownes anything to psychological theories.

Ultimately, Peirce came to think that it is his diagrammatic theory of existential graphs that provides the key to the logical relationship between signs and the interpreting mind (Pietarinen 2006a, 2011a, LoF).

As far as objects in this troika of signs, objects and interpretants are concerned, their role can be derived from principles resembling Kant's Dinge an sich, pure modes of being. But unlike Kant, Peirce held it meaningless to think that there are objects beyond the reach of intelligent cognition and comprehension. In MS 499, Peirce uses slightly different terminology in explaining the triangle of signs, objects and interpretants and their interplay, suggesting that "the object of the sign is the sign's determinant; the interpretant is the determinand of the sign". The determinant is that which determines something, and the determinand is that which something 
determines. Being determined by and determining something are in no way complete methods of dealing with elements in semeiotic theory, however, as is witnessed by the remark that "a sign has an object and an interpretant. In the interpretant, which is a partially indeterminate thing, the sign determines a Firstness, not absolute but relative to the object. The pairedness it brings about is not absolute or brute, but recognizes the sign as its creator" (LN: 109r, c. 1898). Pairedness obtains between the object and its interpretant, and is mediated by the sign. Signs, so to speak, look backward to the object and forward to the interpretant. The interpretant is partially indeterminate because a sign only determines the firstness, or pure qualities, of the object, and the secondness and thirdness must sprout from the action of the object with its interpreter plus the presence of the mind. The latter two are realized only when the semeiotic process is present in its full capacity.

In a letter to his former student Christine Ladd-Franklin (Pietarinen 2013b), which Peirce wrote to correct an error in one of his earlier letters, the sign-object-interpretant relation is expounded from a somewhat different and unprecedented perspective. Peirce tells that a sign is an "object made by a party we will call the utterer, and determined by his idea, which is the sense or depth of the sign, in order to create in the mind of the interpreter an interpretant idea of the same object. The object is itself really of the nature of a sign, too" (MS L 237: 1, 12 June 1902, Letter to LaddFranklin). Now Peirce admitted that signs may have no utterers, as well as that the utterer and the object may be assimilated with one another (Pietarinen 2003b). All this is consistent with his earlier views on signs, but an interesting twist is that now he admits something more: that signs are objects, and that objects are of the nature of signs. Does not this make signs and objects simply identical, depriving semeiotic much of its triadic interest? The short answer is that signs are not those objects that are signs in the exactly same sense in which objects are signs. There is the meta-theoretic or meta-semiotic level in the study of signs that takes signs as the object of that study, as well as objects of signs that determine (in special senses of that determination) the signs as representations of those objects and interpretants.

Another, related point he makes in this letter is that signs in fact possess three relations: not only do they, so to speak, look back to the object and forward to the interpretant, they also are recursive in relating to their own "senses" or "depths". This sense or depth of the sign is its "better self" (MS L 237: 1). The analogues to the relation between the depth and the sign that he draws are those of "an idea to an ideal" and "memory to vivid hallucination". If such recursions fall within the relation of a sign to its interpretant, then they are like that of a "seed to the plant that grows from it". The upshot is that signs typically are only incomplete representations of what these other relations are. Much like minds, they lack those clear-cut, measurable and observable boundaries that we are misled to think they have. Signs elude formal identification prior to their submission to rigorous scrutiny and analysis. 
A virtually open-ended number of questions presses in on us on the basic character and nature of Peirce's semeiotic. Some of them are presented below in connection to the basic trichotomies. Many such questions were originally posed by Peirce, yet a vast number of them were left unanswered. For example, in the Logic Notebook he asked what the object of an imperative sign could be (LN: 254r, 9 October 1905). He noted that its interpretant was the desired state of things, but no easy solution was to be found as regards its object. This is just one example illustrating the unfinished nature of the system which at the same time is capable of bearing endless fruits and not only anticipations of the 20th-century rediscoveries in theories of language, semantics and pragmatics, logic and communication, and philosophy and logic of science and creative discovery.

\section{Rhema, proposition, argument}

An important categorization of signs in their reference to their interpretants is into rhemas, propositions and arguments. ${ }^{9}$ This trichotomy comprises the major division in the meaning-category side of the sign triad. These three ideas were also essential in the received conception of modern logic, albeit in a narrower sense. Rhemas were typically thought to refer to uninterpreted predicate terms, propositions to assertions with propositional content, and arguments to proofs. Yut not only mathematical proofs but also derivations, deductions, inductions, abductions, sequents, demonstrations, dialogues, disputes and so on are species of arguments or argumentative constructions. Often such arguments are non-demonstrative, such as in rhetoric or abduction. Yet such arguments need not have any less claim for their validity than demonstrative reasoning has.

An uninterpreted rhema gives no information about the objects of the sign and thus cannot by itself have a truth value. Peirce saw its role in the philosophy of logic unmistakable, however, among others in overcoming Kant's deficient programme of logical analysis. Kant's construction of concepts was limited to the production of representatives in the mind that correspond to individuals. Such a construction can use representatives only in the context of proper names, but Peirce broke off from this tradition and thought of the construction of concepts, analogous to Kant's Anschauung, as a selection of not only the representatives of proper names (for rhemas), but also of the representatives of indefinite expressions (for onomas). Peirce's analytic machinery of the existential graphs was calculated to deal with different kinds of indefinites in

9 Some alternative terms Peirce used for rhemas are signs of qualitative possibility, rhemes, rhemata, terms, seme, sumisign; for propositions signs of fact, dicisigns, dicent signs, phemes; and for arguments signs of reason, delomes and suadisigns. 
ways Kant's weak form of analysis was impotent to accomplish. ${ }^{10}$ Propositions, in contrast, do provide information about the objects of the signs. But both rhemas and propositions are would-bes: the former leaves objects and interpretants undetermined while the latter leaves its interpretant unrealised.

Symbols, and in some sort other Signs, are either Terms, Propositions, or Arguments. A Term is a sign which leaves its Object, and a fortiori its Interpretant, to be what it may. A Proposition is a sign which distinctly indicates the Object which it denotes, called its Subject, but leaves its Interpretant to be what it may. An Argument is a sign which distinctly represents the Interpretant, called its Conclusion, which it is intended to determine. That which remains of a Proposition after removal of its Subject is a Term (a rhema) called its Predicate. (CP 2.95, c.1902, General and Historical Survey of Logic: Partial Synopsis of a Proposed work in Logic)

According to Peirce, these signs are representamens:

A representamen is either a rhema, a proposition, or an argument. An argument is a representamen which separately shows what interpretant it is intended to determine. A proposition is a representamen which is not an argument, but which separately indicates what object it is intended to represent. A rhema is a simple representation without such separate parts. (CP 5.139, 1903, Lectures on Pragmatism: The Three Kinds of Goodness)

The notion of interpretant in this triplex typically refers to final interpretants, as it concerns the end results of a piece of rational inquiry.

\section{Abduction, deduction, induction}

Peirce subdivided simple arguments into three kinds: abduction, deduction and induction. My remarks are limited to the question of how Peirce sees these types to correlate with the icon-index-symbol triad (of the latter, see below).

10 See Pietarinen 2006a; Bellucci, Pietarinen in press. In brief, the spots in existential graphs are of two kinds, rhemata or onomata. In contrast to rhemas, whose blanks are filled with proper names, onomas admit of indefinites: "Each onoma is an arbitrary index of an indefinite individual. A connecting line may abut upon it, and this has the effect of attaching the onoma, as a designation, to the individual which that line denotes. I usually write capital letters for onomata. A spot has a definite place upon its periphery, called a hook, corresponding to each blank; and to each hook an extremity of a line of connection may be attached with the effect of filling the blank with a designation of the individual denoted by the line" (MS 491: 3-4). What is common in both rhemas and onomas is that they are incomplete predicates and get their values from the dialogic and semeiotic process of selecting proper names and indefinites. 
An abductive argument has a relation of similarity between the facts stated in the premisses and the facts stated in the conclusion, without compelling one to accept the truth of the conclusion when the premises are true. Peirce states that the facts in the premisses of an abductive argument constitute an icon of the facts in the conclusion, asserted positively and admitted with suitable inclination. It is in this sense that abduction starts a new idea; in Peirce's words, it is "originary" (CP 2.96; Ma, Pietarinen in press).

Deduction is "an argument representing facts in the Premiss, such that when we come to represent them in a Diagram we find ourselves compelled to represent the fact stated in the Conclusion" (CP 2.96). The notion of index arises here, in that "the Conclusion is drawn in acknowledgment that the facts stated in the Premiss constitute an Index of the fact which it is thus compelled to acknowledge" (CP 2.96). It is in this sense that deduction is demonstrative reasoning, in Peirce's terms "obsistent" and "compulsive" (see Bellucci, Pietarinen "Charles Sanders Peirce: Logic"). ${ }^{11}$

Induction is an argument starting from a hypothesis that is a result of abduction, interspersed with results of possible experiments deduced from hypotheses and selected independently of any epistemic access to its truth value. Peirce called them "virtual predictions". The hypothesis is concluded "in the measure in which those predictions are verified, this conclusion, however, being held subject to probable modification to suit future experiments" (CP 2.96). The relation between the facts stated in the premisses and the facts stated in the conclusion of inductive arguments is symbolic, as "the significance of the facts stated in the premisses depends upon their predictive character, which they could not have had if the conclusion had not been hypothetically entertained" (CP 2.96). In Peirce's terminology, inductive arguments are "transuasive" in their assurance of the amplification of positive knowledge.

\section{Icon, index, symbol}

Inherent in the above distinction is the triad of index, icon and symbol. Peirce held this to be a central trichotomy in the object-category side of the sign triad. It is explained in a draft of his famous article "A guess at the riddle", one of his attempts to unify and draw together his thought, as follows: ${ }^{12}$

There may be a mere relation of reason between the sign and the thing signified; in that case the sign is an icon. Or there may be a direct physical connection; in that case, the sign is an index. Or there may be a relation which consists in the fact

11 Bellucci, Francesco; Pietarinen Ahti-Veikko "Charles Sanders Peirce: Logic" has been retrieved from the Internet Encyclopedia of Philosophy http://www.iep.utm.edu/peir-log/.

12 Cf. MS 909, A Guess at the Riddle; CP 1.354-416; EP 1: 245-279; W 6: 166-210. 
that the mind associates the sign with its object; in that case the sign is a name [or symboll. Now consider the difference between a logical term, a proposition, and an inference. A term is a mere general description, and as neither icon nor index possesses generality, it must be a name; and it is nothing more. A proposition is also a general description, but it differs from a term in that it purports to be in a real relation to the fact, to be really determined by it; thus, a proposition can only be formed of the conjunction of a name and an index. An inference, too, contains a general description. (MS 909; CP 1.372, 1887-88).

A related composition provides an explication of icons, indices and symbols:

There are three kinds of signs which are all indispensable in all reasoning; the first is the diagrammatic sign or icon, which exhibits a similarity or analogy to the subject of discourse; the second is the index, which like a pronoun demonstrative or relative, forces the attention to the particular object intended without describing it; the third [or symbol] is the general name or description which signifies its object by means of an association of ideas or habitual connection between the name and the character signified. (CP 1.369, c.1885)

All reasoning is diagrammatic and iconic, Peirce maintains. Indexical signs such as those exhibited in demonstratives, anaphoric pronouns and intentional statements may have some very concrete or even physical connection to objects, yet are difficult to comprehend by automated reasoning systems. The reason is that what is meant by a "physical connection" is not unique. Research on automated reasoning systems came to adopt the symbolic aspect of the sign as dominant, but it did so for largely misplaced reasons as symbols were thought to be easier to handle by standard techniques such as conventions, recursion and implicit definitions.

\section{Genuine and degenerate signs}

According to Peirce, signs may also be genuine or degenerate, and be so to varying degrees. He describes these divisions in Partial Synopsis of a Proposed Work in Logic (CP 2.92, c. 1902) such that a sign that is degenerate to a lesser degree is an "obsistent sign" (index) and has a genuine relation to its object independently of what its interpretant is. Examples of obsistent signs are exclamations as indicative of danger, and a rap on the door as indicative of a visitor.

A sign that is degenerate to a greater degree is an "originalian sign" (icon), which has its significance purely in its quality. An example of this is imagining how

I would act under certain circumstances, as showing me how another man would be likely to act. We say that the portrait of a person we have not seen is convincing. 
So far as, on the ground merely of what I see in it, I am led to form an idea of the person it represents, it is an Icon. But, in fact, it is not a pure Icon, because I am greatly influenced by knowing that it is an effect, through the artist, caused by the original's appearance, and is thus in a genuine Obsistent relation to that original. Besides, I know that portraits have but the slightest resemblance to their originals, except in certain conventional respects, and after a conventional scale of values, etc. (CP 2.92)

Third, a genuine sign is, in Peirce's terms, "transuasional" (symbol), a sign that is only realized by its interpretant and exemplified in any utterance of speech: "The words only stand for the objects they do, and signify the qualities they do, because they will determine, in the mind of the auditor, corresponding signs. The importance of the above divisions, although they are new, has been acknowledged by all logicians who have seriously considered them" (CP 2.92).

Peirce went on to draw the grand triune of firstness, secondness and thirdness into his dichotomy of genuine and degenerate signs:

An Index or Seme (séma) is a Representamen whose Representative character consists in its being an individual second. If the Secondness is an existential relation, the Index is genuine. If the Secondness is a reference, the Index is degenerate. A genuine Index and its Object must be existent individuals (whether things or facts), and its immediate Interpretant must be of the same character. But since every individual must have characters, it follows that a genuine Index may contain a Firstness, and so an Icon as a constituent part of it. Any individual is a degenerate Index of its own characters. (CP 2.283, 1902-03, Speculative Grammar: The Icon, Index, and Symbol)

Existentially bound variables in quantified logic serve as present-day examples of genuine indexical signs, whereas free variables are degenerate.

\section{Particular, singular, universal propositions}

General subjects of propositions are either particular or universal. In addition, propositions may themselves be also singular. Peirce took particular propositions to be those that transfer the "liberty of choice to the other party, the utterer, and consequently the defender of the proposition". ${ }^{13}$ Similarly, a singular proposition is "one which leaves no liberty of choice as to the singular instance, to either party" (MS 515: 20).

13 MS 515: 20, On the First Principles of Logical Algebra (First Print). To appear in LoF. 
These statements derive from more essential considerations. According to Peirce, every proposition is in every aspect either definite or individual. Definite signs or propositions are those to which the principle of contradiction applies, and individual signs or propositions are those to which the principle of excluded middle applies. These two logical principles are, he rightly claims, derived of more general considerations about logical activities, and are not as such beyond dispute. Those general considerations pertain to the most general relations between signs, logical reasoning and the notion of communication between the utterers and the interpreters of the signs (Pietarinen 2013a).

Universal propositions are those that are non-individual and thus definite, whereas particular propositions are indefinite and thus individual. Singular propositions, then, are those that are both definite and individual. ${ }^{14}$

The dual of the universal proposition, the particular proposition, does not presuppose existence. In fact, existence itself consists of the fact that some particulars are true of them. A particular statement, some $P$, is true not only when some $P$ will be a particular statement, but also when $P$ in the statement is replaced by something that actually exists. Defining existence is an altogether different matter. For Peirce, it involves the category of secondness, a confrontation of action and reaction, force and resistance, acts of perception without freedom to choose and interpret, an ongoing duel between the ego of the momentary self and the non-ego of another momentary self. Secondness culminates in the definition of existence as a choice that leaves no genuine option concerning the application of a predicate: "A proposition which, in like manner, leaves its interpreter no freedom of choice as to what it is to be applied to, namely, a singular or a particular proposition, asserts existence, - i.e. not merely universally predicates existence, but represents that there is, will be, (or would be, but this amounts to nothing unless it leads to a 'will be') a perceptive act in which that which is indicated is forced upon said interpreter" (MS 690). ${ }^{15}$

Existence is occurrence in the universe of discourse. There are countless existences just as there are countless occurrences. A singular collection may be picked from the universe by virtue of its co-occurrence with those that exist. Not all there is in the universes of discourse has existence: other universes of discourse, or the dimensions of the universe can concern entities such as modalities, possible individuals, eventualities, actions, interrogatives, imperatives, or tenses. The occurrences of singulars are the focal points to which the utterer and the interpreter draw their attention: "when

14 MS 515: 20; MS 690, c. 1901, On the Logic of Drawing History from Ancient Documents, Especially from Testimonies, reprinted partially in EP 2:75-114 and in CP 7.164-231 and, most comprehensively, in W6.

15 From the missing page 2 of the original HP: 737, reprinted in Companion to EP 2, Selection 8, Page 98, Line 12, Note 31, Peirce Edition Project, Electronic Supplement. 
the subject is not a proper name, or other designation of an individual within the experience (proximate or remote) of both speaker and auditor, the place of such designation is taken by a virtual precept stating how the hearer is to proceed in order to find an object to which the proposition is intended to refer" (CP 2.357, 1901, Speculative Grammar: Propositions). The need for existential presuppositions for singular existences evaporates in the wake of existence as occurrence.

This possibility of occurrences that do not exist has not been given due attention in the literature. However, it also prompts new questions. For we need to be able to identify occurrences and events in addition to individual objects. And that calls for identification of occurrences ('no eventuality without identity'). Are they the same entities that get repeated in the universe of discourse? Are the occurrences, and not just the objects, vague or indefinite? How to represent the temporal aspect of events and occurrences? ${ }^{16}$

\section{Qualisigns, sinsigns, legisigns}

Peirce's best-known division of signs was into three main trichotomies. The iconindex-symbol one is the second, and is made according to the sign's characters in its relation to its object. The third derives from whether the interpretant represents sign's relation to its object as a sign of possibility, of fact, or of reason, namely as rhemas, propositions (dicisigns) or arguments (CP 2.243, c.1903, Speculative Grammar: Division of Signs). The first concerns the division of signs (or representamens) per se. These are the sign's quality, its actual existence, and its being a general law. These Peirce terms the qualisign, sinsign and legisign, respectively: "A qualisign is a quality which is a Sign. It cannot actually act as a sign until it is embodied; but the embodiment has nothing to do with its character as a sign" (CP 2.244). It is by means of signs of qualities that one defines simple signs, or the sinsigns (tokens), signs of an actually extant entity or event. A sinsign can only exist "through its qualities; so that it involves a qualisign, or rather, several qualisigns" (CP 2.245). Thirdly, a legisign (type) is a law that is a sign, "usually established by men" (CP 2.246). An example is a conventional sign of a general type, the signification of which is by its application. As each individual instance of such an application is a sinsign, every legisign contains sinsigns.

\footnotetext{
16 Time is a well-studied substance of modern logic. Peirce's unacknowledged contribution to its development is noteworthy: he conducted several studies not only on Kant's conception of time but also on the possibility of having a real logic of time, and so time is in no way to be thought to be an extra-logical matter. In LN: 340r (7 January 1909) he considered propositions that "are true sometimes" and those that are true "under all circumstances". Earlier, on 20 September 1905, he hinted that probability calculus depends on an essential property of time of "the future being like the past", which ought to afford the key to the nature of time (LN: 249r).
} 


\section{Ten genera of signs}

Bringing the three main trichotomies together we get the three-fold classification of signs which engenders the ten genera of signs:

$\begin{array}{llll} & \text { Sign } & \text { Object } & \text { Interpretant } \\ \text { Firstness } & \text { Qualisign } & \text { Icon } & \text { Rhema } \\ \text { Secondness } & \text { Sinsign } & \text { Index } & \text { Proposition } \\ \text { Thirdness } & \text { Legisign } & \text { Symbol } & \text { Argument }\end{array}$

There are four reductions and interrelations between cells in this matrix: (1) Every qualisign is an icon; (2) every icon is a rhema; (3) every argument is a symbol; and (4) every symbol is a legisign (MS L 237: 4-5, 27 July 1904). Consequently, Peirce ended up with ten genera of signs: qualisigns, iconic sinsigns, rhematic indexical sinsigns, propositional (dicisignificant) sinsigns, iconic legisigns, rhematic indexical legisigns, propositional (dicisignificant) indexical legisigns, rhematic symbols, propositional (dicisignificant) symbols and arguments (CP 2.264, c. 1903).

It has frequently been acknowledged that the main types of signs and their interrelations and contact points may be represented in a triangular form that has ten signs in the centre, as this arrangement allows for most interactions with other signs. The central place that indexical signs enjoy is by no means coincidental or without consequence: when Peirce discovered his major division of signs he began to regard indexical notions as increasingly prominent not only in his theory of signs but also in the emerging new logic of quantifiers and in the method of existential graphs. That which is called the existential quantifier in the general algebra of logic and that which is the line of identity in existential graphs both make use of indexicality yet need not bear existential presuppositions (CP 2.283; Pietarinen 2006a).

\section{Informed, essential, and substantial breadth and depth}

These notions throw us back to the early phases of the development of Peirce's architectonics. The act of predication, namely the joining of the object to its subject, is a way of increasing the logical breadth of a sign without diminishing its logical depth. Breadth and depth refer to what more customarily is known as the denotation and connotation of logical terms.

Peirce classified breadth and depth as informed, essential and substantial. The informed breadth of a term means "all the real things of which it is predicable, with logical truth on the whole in a supposed state of information" (CP 2.407, 1867). The informed depth means "all the real characters which can be predicated of it (with logical truth, on the whole) in a supposed state of information" (CP 2.408). 
The ground of the object was taken in Peirce's early philosophy to refer to the connotation of a symbolic sign, the second of the three-way notion of reference. The first is the direct reference of a symbol to its objects, namely the denotation of the symbol. The second, connotation, is the reference of the symbol to the common characters of its object, in other words, to its ground through its object. The third is the reference of the symbol to its interpretants through its object, which Peirce termed the information of the symbol.

The symbol's direct reference to its object is an example of informed breadth, and its reference to the ground of the object is an example of informed depth.

Whatever reference there is to its interpretant is the information concerning the symbol (CP 2.418). Later, Peirce subsumed the ground under interpretants. The informed breadth and depth of a term lie between the two extremes of the states of information of which no fact is known and of which there is perfect knowledge of all there is. So there are two other states of information that correspond to these extremities. First, Peirce distinguishes the essential depth of a term, by which he means "the really conceivable qualities predicated of it in its definition" (CP 2.410). The second is the substantial breadth of the term, "the aggregate of real substances of which alone a term is predicable with absolute truth". The substantial depth, in turn, "is the real concrete form which belongs to everything of which a term is predicable with absolute truth" (CP 2.414). For completeness, the essential breadth is all the objects the sign refers to by virtue of the definition of the object offered through the interpretant.

Peirce did not distinguish the three aspects of breadth and the three aspects of depth from one another by the distinction of supposed vs. imaginary states of information. One might have expected such a distinction in the light of the later idea of intensions, or modalities that involve multiplicities of different 'possible worlds' in which statements are evaluated. But his notion of a "perfect state of information", as it was phrased in the late MS 664, could be taken to correspond to sets of possible worlds according to which all worlds are linked by equivalence relations (MS 664, The Rationale of Reasoning, November 1910). The "perfect state" explains what it means that the representation of all the characters involved in the uttered word is the state that contains no ignorance (Pietarinen 2006b).

Peirce's struggles with the breadth and depth in his early writings called for more extensive divisions of signs that also take objects and interpretants into account. In particular, Peirce classified interpretants in manifold ways. It is here that we are witnessing the emergence of a truly dynamic and nearly complete theory of signs.

\section{Varieties of interpretants}

Signs cannot stand alone. The ways in which they represent or impart information of objects is given by a further development of signs. Signs are interpreted as something or 
as signifying things, typically with reference to their interpreters. Such interpretation is itself a sign, but a subsequent one not identical to the interpreted sign. This subsequent sign is the interpretant of the previous sign. We can think of it as the value of a function, or as a functional interpretation of a sign.

The relation of every sign to its object and its interpretant is triadic, manifesting the thesis that three-place relations cannot be composed out of one and two-place relations alone. While a sign represents objects, and in virtue of that representation conveys something about it, the idea that the sign gives rise to is its interpretant. It is this idea of the sign that gives us information according to which we can look for its objects.

The system of such functions is sometimes termed semiosis. It is "an action, or influence, which is, or involves, a cooperation of three subjects, such as a sign, its object, and its interpretant, this tri-relative influence not being in any way resolvable into actions between pairs" (CP 5.484, 1907, A Survey of Pragmaticism). Although the term 'semiosis' is merely a hapax in Peirce's corpus, the idea behind it is commonplace.

The representation of an object by a sign is therefore mediated in its interpretants. Interpretants need not materialize in the mind. If there is no such material part for the interpretants, we can regard interpretations of objects deferred indefinitely into the future. Interpretants need not be actualized: there is an element of potentiality and modality in them.

The following snippet makes a helpful distinction between three kinds of interpretants, namely immediate, imperfect and indirect interpretants:

Although the immediate Interpretant of an Index must be an Index, yet since its Object may be the Object of an Individual [Singular] Symbol, the Index may have such a Symbol for its indirect Interpretant. Even a genuine Symbol may be an imperfect Interpretant of it. So an icon may have a degenerate Index, or an Abstract Symbol, for an indirect Interpretant, and a genuine Index or Symbol for an imperfect Interpretant. (CP 2.294, c. 1902)

This passage suggests that the first group refers to several kinds of immediate interpretants related to the anterior states of information and initial stages of semiosis. They give what the common sense is prone to call the meaning. Among the immediate ones are: (1) essential interpretants, which come in minimal states of information; (2) the lowest grades of word meaning in initial states of information; (3) intentional interpretants, or those determined in the mind of the utterer; and (4) immediate interpretants, or those which the signs express without interference from the utterer or the interpreter, such as grammatical, morphosyntactic and phonological aspects of when linguistic signs are in question.

The second group includes dynamic interpretants, which carry further the objective content of the actual, synchronic processes of interpretation. Because they are related to interpretation, they do not consist exclusively of dynamic interpretants, which 
Peirce defined as "the actual effect which the Sign, as a Sign, really determines" (CP 4.536, 1906, Prolegomena). They also encompass effectual interpretants, which are the interpretants produced in the minds of the interpreters by the signs uttered or intended to be uttered by the utterer.

At the receiving end of semiosis rests, thirdly, the class of final interpretants. They are "that which would finally be decided to be the true interpretation if consideration of the matter were carried so far that an ultimate opinion were reached" (CP 8.184, 1903, Review of Lady Welby, What is Meaning?; Pietarinen 2009). Many types of final interpretants are found in Peirce's various attempts to complete his system of semeiotic. (1) Communicational interpretants are those that are common and shared in semiosis, conceived of as a communicational and dialogical act of interpretation. Their successful mediation requires common ground with presuppositions and knowledge drawn from common experiences. (2) Final, habitual or logical interpretants give rise to habits, that is, modifications to participants' dispositions and beliefs of acting in a certain way in certain circumstances. (3) Rational, normal or final interpretants are value-bound, normative interpretants used in judging other forms of final interpretants. (4) Eventual, final, normal or ultimate logical interpretants designate maximal states of information with no ignorance, and so there the sign's object and the interpretant become one. Maximal states of information are given in the substantial depth and breadth of the symbol.

Thus iterations of interpretations do reach those final, terminating nexûs that reveal relevant information about the object and its reality. No infinite or endless semiosis is to be feared of.

Around 1906 Peirce nevertheless had to "confess that my own conception of this third interpretant is not yet quite free from mist" (CP 4.536). The later writings clarify it in no significant degree, but the emphasis on the role of communicational interpretants that grew after 1906 sheds new light on this class. By August 1906, in referring to his attempts to classify interpretants Peirce admitted that his notions are too narrow, adding that “instead of 'Sign', ought I not to say Medium?” (LN: 283r).

The classification of interpretants presented here is convincing in its extensive coverage of Peirce's corpus. It shows that interpretants are the dynamic, informational, epistemic and communicational states of those who participate in semiosis. The accuracy of the classification, given in a synoptic form in the Logic Notebook, ${ }^{17}$ is vindicated by his admission two days later that he had drawn this synopsis without recollecting anything about his earlier divisions of interpretants.

Whether we fully believe the veracity of this admission or not, the chief aspect of semiosis is that the participants are not only, or even principally, any actual utterers

17 See e.g. 288r-289r, 23 October 1906, as well as the transcriptions in the "Division of signs", this issue. 
and interpreters in concrete conversational settings. Semiosis concerns imaginary thought-experiments, and what would or could be there in the quasi-minds of quasiutterers and quasi-interpreters, especially as represented in diagrammatic forms (MS 293, PAP, late 1906 to early 1907). Such imaginary contents of the Phemic sheet, as a representation of what Peirce terms the phaneron, and the analysis of both formal and material parts of the indecomposable elements of the phaneron in the system of existential graphs, was thought by Peirce to be essential to the ultimate erection of the theory of signs, especially as one needs to deal in those final divisions with conditionals, non-declarative assertions, moods and modalities, commands, questions, speech acts, feelings, intentions, and so on, and to logically analyse their meaning (Pietarinen 2005b, 2006a, 2008, LoF).

The following passage confirms that objects also are categorized according to similar principles. No Kantian noumena transpire: the two kinds of objects, immediate and dynamic, are the necessary and sufficient ones in the object-category side of the triad:

I have already noted that a Sign has an Object and an Interpretant, the latter being that which the Sign produces in the Quasi-mind that is the Interpreter by determining the latter to a feeling, to an exertion, or to a Sign, which determination is the Interpretant. But it remains to point out that there are usually two Objects, and more than two Interpretants. Namely, we have to distinguish the Immediate Object, which is the Object as the Sign itself represents it, and whose Being is thus dependent upon the Representation of it in the Sign, from the Dynamical Object, which is the Reality which by some means contrives to determine the Sign to its Representation. (CP 4.536)

A passage written around the same time corroborates this dichotomy of objects: "There are an Immediate Interpretant and a Dynamical Interpretant corresponding closely to the Immediate and Dynamical Objects. But there is, in addition, a Final Interpretant, to which no particular kind of object corresponds". ${ }^{18}$

An alternative trichotomy for interpretants is put forward in CP 5.475-476 [1906-07, A Survey of Pragmaticism]. The first is the emotional interpretant, which concerns feelings produced by the sign. Peirce did not consider this to be a useful effect of the signs as far as the truth is concerned, but sometimes emotion is the sole interpretant that the sign produces and sometimes it could be of use in dealing with ethical and other matters of vital importance, or even in getting scientific inquiry off the ground. Second, the energetic interpretant is a further significant effect of the emotional interpretant, a mental or physical effort or act. Finally, the logical interpretant, as described above, produces an effect so forceful as to give rise to a habit change (Pietarinen 2005a).

18 MS 295: 28, 1906, rejected pages for the Monist article of 1906. To appear in LoF. 
The activity takes the form of experimentation in the inner world; and the conclusion (if it comes to a definite conclusion), is that under given conditions, the interpreter will have formed the habit of acting in a given way whenever he may desire a given kind of result. The real and living logical conclusion is that habit; the verbal formulation merely expresses it. I do not deny that a concept, proposition, or argument may be a logical interpretant. I only insist that it cannot be the final logical interpretant, for the reason that it is itself a sign of that very kind that has itself a logical interpretant. The habit alone, which though it may be a sign in some other way, is not a sign in that way in which that sign of which it is the logical interpretant is the sign. The habit conjoined with the motive and the conditions has the action for its energetic interpretant; but action cannot be a logical interpretant, because it lacks generality. The concept which is a logical interpretant is only imperfectly so. It somewhat partakes of the nature of a verbal definition, and is as inferior to the habit, and much in the same way, as a verbal definition is inferior to the real definition. The deliberately formed, self-analyzing habit - self-analyzing because formed by the aid of analysis of the exercises that nourished it - is the living definition, the veritable and final logical interpretant. Consequently, the most perfect account of a concept that words can convey will consist in a description of the habit which that concept is calculated to produce. But how otherwise can a habit be described than by a description of the kind of action to which it gives rise, with the specification of the conditions and of the motive? (CP 5.491, 1906-07, A Survey of Pragmaticism)

Alternative readings of this paragraph refer to the role of habits in interpretation. Such a perspective has significant logical and pragmatistic repercussions addressed in Pietarinen (2006a, Ch. 3). The tentative reductions that can be gleaned from Peirce's records in the Logic Notebook suggest that emotional, energetic and logical interpretants are subsumed by immediate and dynamic interpretants, whereas all the final ones are logical (LN: 299r, 23 October 1906). The quotation above asserts that not all logical interpretants are final. An immediate interpretant in its firstness is a quality of feeling and is thus emotional, and a dynamic interpretant in its secondness encompasses an exertion of force and is thus energetic. Since dynamic interpretants are not final, this effect produced upon the interpreter may be a feeling.

Further divisions arise in Peirce's later work. The triplet of impressional, factual and habitual interpretants is put forward in LN: 283r [30 August 1906]. Earlier, the "proper interpretant" (MS L 427: 4, 25 July 1904) is meant to be the sign's relation in respect to its aspect of thirdness, over and above the respects of firstness and secondness. It is the "naïve understanding of the sign" (MS L 427: 4), which does not possess the qualities of a "reflective" interpretant. Peirce also talks about objective, actual, middle, rational and normal interpretants, but here his descriptions remain incomplete. Such differences in interpretants as epitomized in his later writings became central to the erection of his philosophy of pragmati(ci)sm and its proof (Pietarinen, Snellman 2005; 
Pietarinen 2011b). For further information on the division of interpretants, the reader is referred to the transcription in this issue of those classes that Peirce himself came to highlight as well as to the abundant secondary literature. ${ }^{19}$

\section{References}

\section{Editions of Peirce's writings}

Peirce, Charles S. 1839-1914. Manuscripts. Charles Sanders Peirce Papers (MS Am 1632). Houghton Library, Harvard University. [1966: The Charles S. Peirce Papers, Microfilm Edition, Thirty Reels with Two Supplementary Reels Later Added. Cambridge: Harvard University Library Photographic Service. Catalogued in Robin, Richard S. 1967. Annotated Catalogue of the Papers of Charles S. Peirce. Amherst: University of Massachusetts Press.] [MS]

- (ed.) 1883/1983. Studies in Logic. (Fisch, Max, intr.; Eschenbach, Achim, preface.) Amsterdam: John Benjamins. [SiL]

- 1931-1958. Collected Papers of Charles Sanders Peirce. (8 vols. Hartshorne, Charles; Weiss, Paul, eds., vols. 1-6; Burks, Arthur W., ed., vols. 7-8.) Cambridge: Harvard University Press. [CP]

- 1940. Philosophical Writings of Peirce. (Buchler, Justus, ed.; first published as The Philosophy of Peirce: Selected Writings.) New York: Harcourt, Brace and Company. [PW]

- 1976. The New Elements of Mathematics by Charles S. Peirce. (Eisele, Carolyn, ed.) The Hague: Mouton. [NEM]

- 1977. Semiotic and Significs: The Correspondence between Charles S. Peirce and Victoria Lady Welby. (Hardwick, Charles S., ed.) Bloomington: Indiana University Press. [SS]

- 1982-. Writings of Charles S. Peirce: A Chronological Edition. (Volume I 1857-1866, 1982; Volume II 1867-1871, 1984; Volume III 1872-1878, 1986; Volume IV 1879-1884, 1989; Volume V 1884-1886, 1993; Volume VI 1886-1890, 2000; Volume VIII 1890-1892, 2010. Ed. by the Peirce Edition Project.) Bloomington: Indiana University Press. [W]

- 1985. Historical Perspectives on Peirce's Logic of Science: A History of Science. (2 parts; Eisele, Carolyn, ed.) Berlin: De Gruyter. [HP]

- 1992. Reason and the Logic of Things: The Cambridge Conferences Lectures of 1898. (Ketner, Kenneth Laine, ed.) Cambridge: Harvard University Press. [RLT]

- 1992, 1998. The Essential Peirce. (2 vols.; Houser, Nathan; Kloesel, Christian; the Peirce Edition Project, eds.) Bloomington: Indiana University Press. [EP]

- 1997 Pragmatism as a Principle and Method of Right Thinking: The 1903 Harvard Lectures on Pragmatism by Charles Sanders Peirce. (Turrisi, Patricia Ann, ed.) Albany: State University of New York Press. [PP]

19 An extensive bibliography of Peirce's own writings and publications, as well as of the secondary literature, is given at https://en.wikipedia.org/wiki/Charles_Sanders_Peirce_bibliography. The Commens: Digital Companion to C. S. Peirce website http://www.commens.org/bibliography also contains an updated collection of primary and secondary material on Peirce's work. Entries in the Stanford Encyclopedia of Philosophy (http://plato.stanford.edu/entries/peirce/) and in the Internet Encyclopedia of Philosophy (http://www.iep.utm.edu/peircebi/, http://www. iep.utm.edu/peir-log/) are recommended starting points for further explorations in the land of signs, logic and semeiotic. See also Pietarinen 2014a, 2015; Bellucci, Pietarinen, Stjernfelt 2014. 
- 2009. Charles S. Peirce. The Logic of Interdisciplinarity: The Monist-series. (Bisanz, Elize, ed.) Berlin: Akademie Verlag. [LoI]

- 2010. Philosophy of Mathematics: Selected Writings. (Moore, Matthew E., ed.) Bloomington: Indiana University Press. [PM]

- in press. Logic of the Future: Writings on Existential Graphs. (Pietarinen, Ahti-Veikko, ed.) [LoF]

\section{Other works}

Bellucci, Francesco; Pietarinen, Ahti-Veikko in press. Existential graphs as an instrument for logical analysis. Part 1: Alpha. Review of Symbolic Logic.

Bellucci, Francesco; Pietarinen, Ahti-Veikko; Stjernfelt, Frederik (eds.) 2014. Peirce: Five Questions. Automatic Press/VIP.

Kant, Immanuel 1988[1783]. Prolegomena to Any Future Metaphysics. (A revision of the Carus translation; Beck, Lewis White, intr.) New York: Macmillan.

Ketner, Kenneth Laine 1983. A brief intellectual autobiography by Charles Sanders Peirce. American Journal of Semiotics 2(1/2): 61-83.

Ma, Minghui; Pietarinen, Ahti-Veikko in press. A dynamic approach to Peirce's interrogative construal of abductive logic. IfCoLog Journal of Logics and their Applications.

Pietarinen, Ahti-Veikko 2003a. Peirce's game-theoretic ideas in logic. Semiotica 144: 33-47.

- 2003b. Peirce's theory of communication and its contemporary relevance. In: Nyíri, János Kristóf (ed.), Mobile Learning: Essays on Philosophy, Psychology and Education. Vienna: Passagen Verlag, 81-98.

- 2005a. Cultivating habits of reason: Peirce and the logica utens versus logica docens distinction. History of Philosophy Quarterly 22: 357-372.

- 2005b. The composition of concepts and Peirce's pragmatic logic. In: Machery, Edouard; Werning, Markus; Schurtz, Gerhard (eds.), The Compositionality of Concepts and Meanings: Foundational Issues. Frankfurt: Ontos-Verlag, 247-270.

- 2005c. Compositionality, relevance and Peirce's logic of existential graphs. Axiomathes 15: 513-540.

- 2006a. Signs of Logic: Peircean Themes on the Philosophy of Language, Games, and Communication. (Synthese Library 329.) Dordrecht: Springer.

- 2006b. Peirce's contributions to possible-worlds semantics. Studia Logica 82: 345-369.

- 2008. Diagrammatic logic of existential graphs: A case study of commands. In: Stapleton, Gem; Howse, John; Lee, John (eds.), Diagrammatic Representation and Inference. (Lecture Notes in Computer Science 5223.) Heidelberg: Springer, 404-407.

- 2009. Significs and the origins of analytic philosophy. Journal of the History of Ideas 70(3): 467-490.

- 2011a. Existential graphs: What the diagrammatic logic of cognition might look like. History and Philosophy of Logic 32(3): 265-281. [In Chinese: 阿赫提-维科窑皮尔塔瑞南 (2014), 存 在图: 院逻辑和认知. Philosophical Analysis 5(1): 15-35. In Russian: Пиетаринен, А.-B. 2014. Экзистенциальные графы: К вопросу о диаграмматической логике познания. (Лисанюк, Е. Н.; Павлова, А. М., пер.) Логико-философские штудии 12: 39-64.]

- 2011b. Moving pictures of thought II: Graphs, games, and pragmaticism's proof. Semiotica 186: 315-331.

- 2013a. Logical and linguistic games from Peirce to Grice to Hintikka (with comments by J. Hintikka). Teorema 33(2): 121-136. 
- 2013b. Christine Ladd-Franklin's and Victoria Welby's correspondence with Charles Peirce. Semiotica 196: 139-161.

- 2014a. Extensions of Charles S. Peirce: An interview with Ahti-Veikko Pietarinen. Signs \& Media 9: 48-67.

- 2014b. Two papers on existential graphs by Charles S. Peirce: 1. Recent developments of existential graphs and their consequences for logic (MS 498, 499, 490, S-36, 1906); 2. Assurance through reasoning (MS 669, 670, 1911). Synthese 192: 881-922.

- (ed.) 2015. Synthese 192. (Special issue on Peirce's logic and philosophy of language.)

Pietarinen, Ahti-Veikko; Bellucci, Francesco 2014. New light on Peirce's conceptions of retroduction and scientific reasoning. International Studies in the Philosophy of Science 28(2): 1-21.

Pietarinen, Ahti-Veikko; Snellmann, Lauri 2005. On Peirce's late proof of pragmaticism. In: Aho, Tuomo; Pietarinen Ahti-Veikko, Truth and Games. Acta Philosophica Fennica 78: 275-288.

Stuhr, John J. (ed.) 1987. Classical American Philosophy: Essential Readings and Interpretive Essays. Oxford: Oxford University Press, 26-31.

\section{Систематическое изучение знаков: приглашение в теорию Пирса}

Дается обзор примечательных тем и понятий, которые встречаются в разных областях пирсовского научного наследия - в теории знаков, их классификациях и категориях, в логике и «семейотике».

\section{Märkide süstemaatiline uurimine: kutse Peirce’i teooria juurde}

See sissejuhatav kirjutis annab ülevaate tähelepanu väärivatest teemadest ja mõistetest, mis esinevad Charles Peirce'i mõttemaailma omavahel seotud valdkondades: märgiteoorias, märkide klassifitseerimises, kategooriates, loogikas ning 'semeiootikas'. 